\title{
A Brief Note about the New Edition
}

This new edition of The Ancient Greek Hero in 24 Hours is shorter than the original edition of 2013:

1. I have omitted most of the addenda that had originally been placed after Hour 7 and after Hour 8 (those added parts, now omitted, are being rewritten as the core of a new book, Ancient Greek Heroes, Athletes, and Poets).

2. I have also omitted most of the footnotes that quote the original Greek texts (the translations are of course not omitted).

3. I have thinned out many references, in footnotes, to earlier phases of my relevant argumentation, as published elsewhere, especially where I find that such references are not needed for understanding the immediate context of my present argumentation.

4. I have eliminated bibliographical data, in the References at the end, about works that are not signaled in the footnotes.

Any piece of content that has been omitted in this new edition can easily be retrieved in the online version of the original edition, http://nrs.harvard.edu/urn -3:hul.ebook:CHS_NagyG.The_Ancient_Greek_Hero_in_24_Hours.2013. 

THE ANCIENT GREEK HERO in 24 Hours 
